This is an electronic reprint of the original article. This reprint may differ from the original in pagination and typographic detail.

Author(s): Kontinen, Tanja; Ojala, Arto

Title: $\quad$ The internationalization of family businesses: A review of extant research

Year: $\quad 2010$

Version:

Please cite the original version:

Kontinen, T. \& Ojala, A. (2010). The internationalization of family businesses: A review of extant research. Journal of Family Business Strategy, 1 (2), 97-107.

All material supplied via JYX is protected by copyright and other intellectual property rights, and duplication or sale of all or part of any of the repository collections is not permitted, except that material may be duplicated by you for your research use or educational purposes in electronic or print form. You must obtain permission for any other use. Electronic or print copies may not be offered, whether for sale or otherwise to anyone who is not an authorised user. 


\title{
The Internationalization of Family Businesses: A Review of Extant Research
}

\author{
Tanja Kontinen and Arto Ojala, University of Jyväskylä
}

\begin{abstract}
Among family businesses (FBs) internationalization has become a strategy for growth, and sometimes even for survival. This review article presents an analysis conducted on 25 refereed journal articles on FB internationalization. The articles typically portrayed the internationalization of FBs as a sequential process following the Uppsala model of internationalization; by contrast, some FBs were regarded as "born-again" global firms. In methodological terms, most of the articles focused on what-questions rather than why/how-questions. The articles did not make much use of internationalization or FBspecific theories. Our study takes a step towards clarifying the following issues: (i) the current state of knowledge of the phenomenon, (ii) the kinds of background theories applied, and (iii) the methodological approaches utilized. Based on our findings, we map out areas of research that are likely to advance the field of FB internationalization.
\end{abstract}

Keywords: internationalization, family-owned business enterprise, review

\section{Introduction}

The internationalization of family businesses (FBs) is developing into a significant research area (e.g. Sciascia, Mazzola, Astrachan \& Pieper, in press). FBs have traditionally operated in domestic markets, but increasingly find themselves obliged to internationalize, in order to survive in a market that is becoming more and more globally competitive. Since the internationalization of FBs may differ from internationalization of firms with different ownership structures (Bell, Crick \& Young, 2004; Fernandez \& Nieto, 2006; George, Wiklund \& Zahra, 2005; Graves \& Thomas, 2004, 2006; Johanson \& Vahlne, 2009), it is important to investigate FBs as a distinct entity, and attempt to identify their specific features in the context of internationalization. For instance, it has been suggested that FB owner-managers may seek to maximize revenues from a limited number of foreign markets rather than aggressively pursue internationalization on a broader front (Zahra, 2003). There is also a view that FBs may have difficulties in building up a portfolio of strategic resources, and that this will make their international success more difficult (Fernández \& Nieto, 2006).

Since nearly twenty years have passed since the first articles on the internationalization of FBs emerged in journals, it is time to evaluate the past and make suggestions for the future. In this article we shall address the following research questions: (i) What kinds of methodologies and theories have been used to study the 
phenomenon of FB internationalization? (ii) What is the current state of knowledge concerning the internationalization of FBs? (iii) How could the phenomenon be studied in the future in order to further develop knowledge concerning FB internationalization? We shall answer these questions through a review of existing academic articles, and consider future directions for research. For this purpose we shall apply the findings of our review to the three aspects that are particularly important in FB internationalization, namely the family business dimension, the international business dimension, and international entrepreneurship dimension.

Casillas, Acedo and Moreno (2007) reviewed twelve articles on FB internationalization in their book International Entrepreneurship in Family Businesses. However, no reviews exist in academic journals. The need for reviews to advance research in specific related fields has, in fact, been noted by several researchers (e.g. Coviello \& Jones, 2004; Keupp \& Gassmann, 2009). Following this path, Wright, Westhead and Ucbasaran (2007) and Johanson and Vahlne (2009) have pointed out the potential usefulness of research on different kinds of ownership structures - such as family ownership - in the internationalization process. Furthermore, recent findings by Sciascia et al. (in press) indicate that different levels of family ownership affect the internationalization of these firms.

\section{Methodology}

In conducting the review, we adopted the basic guidelines for a systematic review set out by Transfield, Denyer and Smart (2003). Thus, our review process consisted of three stages: 1) planning the review, 2) conducting the review, and 3) reporting and dissemination (for further details, see Transfield et al., 2003). Initially, we identified relevant family business internationalization articles by conducting a keyword search in nine databases: Inderscience, Business Source Elite (EBSCO), Emerald, Informaworld, JSTOR, SAGE Journals Online, Science Direct (Elsevier), Springerlink, and ISI Web of Knowledge. The relevant keywords for the searches were drawn from the literature on internationalization and FBs. We formed combinations of the terms internationalization, entry process, entry, international operations, international trade, globalization, ownership, family firm, family-owned business enterprise, family corporation, and family involvement. To ensure thorough coverage, we also conducted a manual search in the most important source of family business research, namely Family Business Review. In addition, we used Google Scholar (Google), Live Academic Search (Microsoft), Scirus (Elsevier), and Oaister (University of Michigan) to find relevant articles in the field.

To be accepted for the review, the studies had to be published in peer-reviewed academic journals before 2009. Three of the articles found in the databases were excluded from the analysis on the grounds that internationalization was not in fact the phenomenon examined in them (McKibbin \& Pistrui, 1997; Sirmon, Arregle, Fitt \& Webb, 2008), or because the article was written without any references to scientific studies (Vago, 1995). However, the use of a particular theory was not a condition for inclusion: all articles specifically discussing FB internationalization, no matter what 
theory they espoused, were included. In all, 25 articles were accepted for the final review.

In conducting the analysis, we identified the following aspects as critical: methodological issues, theoretical framework(s), topic of research, and main findings and conclusions. Each article found in the databases was analyzed by both of the present authors, working separately. If there were any inconsistent findings, these were discussed to arrive at a common understanding. With 375 units (25 articles $\times 15$ analytical units ${ }^{1}$ ) to analyze, we both ended up with a similar result for 368 of them, yielding a 98.1 percent agreement. The seven units of analysis we needed to discuss concerned the sample size, the theoretical framework, or the main analytical approach of the study in question; these were often poorly reported in the articles.

The articles accepted for the analysis $(\mathrm{N}=25)$ were published in 13 different academic journals (see Table 1). The articles were published between 1991 and 2008. The most relevant articles were found to have been published in the leading ("core") journal in family business studies: 9 of the articles appeared in Family Business Review. Other journals offering more than one article on FB internationalization were Journal of Business Venturing $(\mathrm{N}=2)$, International Journal of Globalization and Small Business $(\mathrm{N}=3)$ and Journal of Small Business and Enterprise Development $(\mathrm{N}=2)$. The other 9 journals all offered one relevant article each. Interestingly, the only journal publishing articles on FB internationalization before the year 2001 was Family Business Review. The majority (14 out of 25) of the articles were published between 2005 and 2008. There was a peak of interest in 2005 with 6 articles, and the years 2006 and 2007 provided 3 articles each. The year 2008 offered 2 articles. All this indicates the contemporary nature of FB internationalization research and the substantially growing interest in the phenomenon. The reasons for this may be the increasing importance of internationalization for FBs and, on the other hand, the fact that (as shown in various studies) the internationalization of FBs appears to differ in many ways from that of non-FBs.

\footnotetext{
${ }^{1}$ The analyzed units were: type of article, country of research, data collection, time frame (year(s) and crosssectional/longitudinal), sample size, response rate, industry type, firm size, FB definition, informants, analytical approach, theories utilized, topic of the article, and main findings and conclusions.
} 


\begin{tabular}{|l|c|c|c|c|c|c|c|c|c|c|c|c|c|c|}
\hline Journal & $\mathbf{1 9 9 1}$ & $\mathbf{1 9 9 3}$ & $\mathbf{1 9 9 6}$ & $\mathbf{1 9 9 9}$ & $\mathbf{2 0 0 0}$ & $\mathbf{2 0 0 1}$ & $\mathbf{2 0 0 2}$ & $\mathbf{2 0 0 3}$ & $\mathbf{2 0 0 4}$ & $\mathbf{2 0 0 5}$ & $\mathbf{2 0 0 6}$ & $\mathbf{2 0 0 7}$ & $\mathbf{2 0 0 8}$ & Total \\
\hline Family Business Review & 1 & 1 & 1 & 1 & 2 & & & & & 1 & 1 & & 1 & 9 \\
\hline $\begin{array}{l}\text { International Journal of } \\
\text { Globalization and Small Business }\end{array}$ & & & & & & & & & 1 & 2 & & & & 3 \\
\hline Journal of Business Venturing & & & & & & & 1 & 1 & & & & & & 2 \\
\hline $\begin{array}{l}\text { Journal of Small Business and } \\
\text { Enterprise Development }\end{array}$ & & & & & & & & & & 1 & & 1 & 2 \\
\hline $\begin{array}{l}\text { International Studies of } \\
\text { Management \& Organization }\end{array}$ & & & & & & 1 & & & & & & & 1 \\
\hline $\begin{array}{l}\text { Management and Organization } \\
\text { Review }\end{array}$ & & & & & & & & & 1 & & & & 1 \\
\hline Baltic Journal of Management & & & & & & & & & & & & 1 & & 1 \\
\hline Journal of General Management & & & & & & & & & & & & 1 & & 1 \\
\hline International Marketing Review & & & & & & & & & & & & 1 & & 1 \\
\hline $\begin{array}{l}\text { Journal of Business and } \\
\text { Entrepreneurship }\end{array}$ & & & & & & & & & 1 & & & & 1 \\
\hline $\begin{array}{l}\text { Journal of International Business } \\
\text { Studies }\end{array}$ & & & & & & & & & & 1 & & & 1 \\
\hline Journal of Management & & & & & & & & & & 1 & & & & 1 \\
\hline $\begin{array}{l}\text { Journal of Small Business } \\
\text { Management }\end{array}$ & & & & & 1 & & & & & & & & 1 \\
\hline Total & 1 & 1 & 1 & 1 & 2 & 1 & 2 & 1 & 1 & 6 & 3 & 3 & 2 & 25 \\
\hline
\end{tabular}

Table 1. Bibliographical sources of the articles reviewed.

\section{Findings}

\subsection{Methodological and definitional issues in the articles reviewed}

The headings in Table 2 below (type of article, country of research, etc.) show the categories we applied in our typology of articles. This section will examine the categories and sub-categories in detail. The articles were written by 33 different authors. The authors with the largest number of publications were Graves and Thomas (in collaboration), who wrote 4 research articles. Gallo, Tsang, Zahra, Fernández, Nieto, Claver, Rienda and Quer all contributed to more than one article (either as single authors or as co-authors). 


\begin{tabular}{|c|c|c|c|c|c|c|c|c|c|c|c|c|c|c|c|c|c|c|c|}
\hline \multirow[t]{2}{*}{ Author(s) } & \multicolumn{3}{|c|}{ Type of article } & \multirow{2}{*}{$\begin{array}{l}\text { Country of } \\
\text { research }\end{array}$} & \multicolumn{2}{|c|}{$\begin{array}{l}\text { Data } \\
\text { collection }\end{array}$} & \multicolumn{3}{|c|}{ Time frame } & \multirow{2}{*}{$\begin{array}{l}\text { Sample } \\
\text { size }\end{array}$} & \multirow{2}{*}{$\begin{array}{l}\text { Response } \\
\text { rate }\end{array}$} & \multirow{2}{*}{$\begin{array}{l}\text { Industry } \\
\text { type }\end{array}$} & \multirow{2}{*}{$\begin{array}{l}\text { Firm } \\
\text { size }\end{array}$} & \multicolumn{4}{|c|}{ FB definition } & \multirow[t]{2}{*}{ Informants } & \multirow{2}{*}{$\begin{array}{l}\text { Analytical } \\
\text { approach }\end{array}$} \\
\hline & 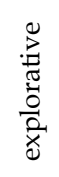 & 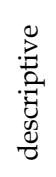 & 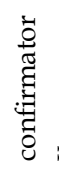 & & ᄅे & 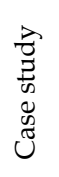 & $\stackrel{\varpi}{\check{\varpi}}$ & 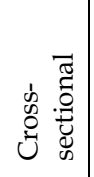 &  & & & & & 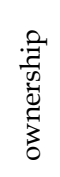 & 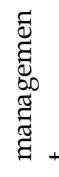 & 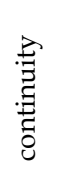 & 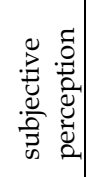 & & \\
\hline $\begin{array}{l}\text { Gallo \& Sveen } \\
\text { (1991) }\end{array}$ & $x$ & & & N/A & & $(\mathrm{x})$ & $\mathrm{N} / \mathrm{A}$ & $x$ & & $\mathrm{~N} / \mathrm{A}$ & - & $\mathrm{N} / \mathrm{A}$ & N/A & $x$ & $\mathrm{x}$ & & & N/A & N/A \\
\hline $\begin{array}{l}\text { Svinth \& } \\
\text { Vinton (1993) }\end{array}$ & $x$ & & & $\mathrm{~N} / \mathrm{A}$ & & $x$ & $\mathrm{~N} / \mathrm{A}$ & $x$ & & 4 & - & manufact & SM & $\mathrm{x}$ & $\mathrm{x}$ & & & owners & $\mathrm{N} / \mathrm{A}$ \\
\hline $\begin{array}{l}\text { Gallo \& Pont } \\
(1996)\end{array}$ & $x$ & & & Spain & $x$ & & $\mathrm{~N} / \mathrm{A}$ & $x$ & & 450 & 21.6 & manufact & SM & $x$ & $x$ & & & $\mathrm{~N} / \mathrm{A}$ & regression \\
\hline $\begin{array}{l}\text { Okoroafo } \\
\text { (1999) }\end{array}$ & & $X$ & & USA & $x$ & & 1997 & & & 500 & $37.4 \%$ & manufact & $\mathrm{L}$ & & & & $x$ & N/A & $\begin{array}{l}\text { descriptive } \\
\text { statistics }\end{array}$ \\
\hline $\begin{array}{l}\text { Davis \& } \\
\text { Harveston } \\
(2000)\end{array}$ & & & $X$ & $\mathrm{~N} / \mathrm{A}$ & $x$ & & $\mathrm{~N} / \mathrm{A}$ & $x$ & & 1078 & $\mathrm{~N} / \mathrm{A}$ & various & SML & & $x$ & & $x$ & $\begin{array}{l}\text { owner- } \\
\text { managers }\end{array}$ & regression \\
\hline Yeung (2000) & $x$ & & & China & & $x$ & 1994 & $x$ & & 3 & - & various & SML & $\begin{array}{c}\mathrm{N} / \\
\mathrm{A}\end{array}$ & & & & executives & $\begin{array}{l}\text { grounded } \\
\text { theory }\end{array}$ \\
\hline Tsang (2001) & $x$ & & & $\begin{array}{l}\text { China and } \\
\text { Singapore }\end{array}$ & & $x$ & $\begin{array}{l}1995 / \\
1996\end{array}$ & $x$ & & 1 & - & manufact & $\mathrm{L}$ & & $\mathrm{x}$ & & & managers & qualitative \\
\hline Tsang (2002) & $x$ & & & $\begin{array}{l}\text { China and } \\
\text { Singapore }\end{array}$ & & $x$ & $\begin{array}{l}1995 / \\
1996\end{array}$ & $x$ & & 10 & - & manufact & $\mathrm{L}$ & $x$ & $x$ & & & managers & qualitative \\
\hline $\begin{array}{l}\text { Child, Ng \& } \\
\text { Wong (2002) }\end{array}$ & $X$ & & & $\begin{array}{l}\text { China } \\
\text { (Hong } \\
\text { Kong) }\end{array}$ & & $\mathrm{x}$ & $\begin{array}{l}2000 / \\
2001\end{array}$ & $x$ & & 5 & - & various & $\mathrm{L}$ & $x$ & & & & $\begin{array}{l}\text { senior } \\
\text { managers }\end{array}$ & qualitative \\
\hline Zahra (2003) & & & $X$ & USA & $x$ & & $\begin{array}{l}1997 \& \\
2000\end{array}$ & & $x$ & 2379 & 22.5 & $\mathrm{~N} / \mathrm{A}$ & N/A & $x$ & & $x$ & & N/A & regression \\
\hline $\begin{array}{l}\text { Graves \& } \\
\text { Thomas (2004) }\end{array}$ & & & $X$ & Australia & $x$ & & $\begin{array}{l}1995- \\
1998\end{array}$ & & $x$ & $* 871$ & $>90$ & manufact & SM & $x$ & $x$ & & & N/A & regression \\
\hline $\begin{array}{l}\text { Casillas \& } \\
\text { Acedo (2005) }\end{array}$ & & & $X$ & Spain & $x$ & & $\mathrm{~N} / \mathrm{A}$ & $x$ & & $* 222$ & 100 & various & SML & $x$ & $x$ & $x$ & & executives & $\begin{array}{l}\text { structural } \\
\text { equation }\end{array}$ \\
\hline $\begin{array}{l}\text { Erdener \& } \\
\text { Shapiro (2005) }\end{array}$ & $X$ & & & - & & $\begin{array}{l}\text { eptu } \\
\text { icle }\end{array}$ & - & $x$ & & - & - & $\mathrm{N} / \mathrm{A}$ & $\mathrm{N} / \mathrm{A}$ & $\begin{array}{r}\mathrm{N} / \\
\mathrm{A}\end{array}$ & & & & executives & conceptual \\
\hline $\begin{array}{ll}\text { Fernandez } & \& \\
\text { Nieto (2005) } & \end{array}$ & & & $X$ & Spain & $x$ & & $\begin{array}{l}1991- \\
1999 \\
\end{array}$ & & $x$ & $* \sim 2000$ & $\mathrm{~N} / \mathrm{A}$ & manufact & $\mathrm{SM}$ & & $x$ & & & $\mathrm{~N} / \mathrm{A}$ & $\begin{array}{l}\text { probit } \\
\text { models }\end{array}$ \\
\hline $\begin{array}{l}\text { George, } \\
\text { Wiklund \& } \\
\text { Zahra (2005) }\end{array}$ & & & $X$ & Sweden & $x$ & & $\begin{array}{l}1997 \& \\
2000\end{array}$ & & $x$ & 2455 & 36 & various & SM & $\begin{array}{c}\mathrm{N} / \\
\mathrm{A}\end{array}$ & & & & executives & $\begin{array}{l}\text { structural } \\
\text { equation }\end{array}$ \\
\hline $\begin{array}{l}\text { Menéndez- } \\
\text { Requejo (2005) }\end{array}$ & & & $X$ & Spain & $x$ & & $\begin{array}{l}2001 / \\
2002 \\
\end{array}$ & $x$ & & 1612 & $\mathrm{~N} / \mathrm{A}$ & $\begin{array}{l}\text { manufact } \\
\text {. }\end{array}$ & SM & $x$ & $x$ & & & N/A & regression \\
\hline $\begin{array}{l}\text { Thomas \& } \\
\text { Graves (2005) }\end{array}$ & & $X$ & & Australia & $x$ & $x$ & $\begin{array}{l}1995- \\
1998 \\
\end{array}$ & & $x$ & $* 871+6$ & $>90$ & manufact & SM & $x$ & $x$ & & & N/A & regression \\
\hline
\end{tabular}




\begin{tabular}{|c|c|c|c|c|c|c|c|c|c|c|c|c|c|c|c|c|c|c|c|}
\hline $\begin{array}{l}\text { Crick, } \\
\text { Bradshaw \& } \\
\text { Chaudry } \\
(2006)\end{array}$ & & $X$ & & UK & $x$ & $\mathrm{x}$ & N/A & $x$ & & $\begin{array}{l}390+ \\
10\end{array}$ & 40 & various & SM & $x$ & $x$ & $x$ & $x$ & managers & $\begin{array}{l}\text { U-tests } \\
\text { qualitative }\end{array}$ \\
\hline $\begin{array}{l}\text { Fernandez \& } \\
\text { Nieto (2006) }\end{array}$ & & & $X$ & Spain & $x$ & & $\begin{array}{l}1991- \\
1999\end{array}$ & & $\mathrm{x}$ & ${ }^{*} \sim 2000$ & N/A & manufact & SM & $x$ & $x$ & & & N/A & $\begin{array}{l}\text { probit } \\
\text { models }\end{array}$ \\
\hline $\begin{array}{l}\text { Graves \& } \\
\text { Thomas (2006) }\end{array}$ & & & $X$ & Australia & $x$ & & $\begin{array}{l}1995- \\
1998\end{array}$ & & $\mathrm{x}$ & *871 & $>90$ & manufact & SM & $x$ & $x$ & & & N/A & $\begin{array}{l}\text { descriptive } \\
\text { statistics }\end{array}$ \\
\hline Basly (2007) & & & $x$ & France & $x$ & & $\mathrm{~N} / \mathrm{A}$ & $x$ & & 764 & 15.4 & various & SM & $x$ & & & & $\mathrm{~N} / \mathrm{A}$ & $\begin{array}{l}\text { structural } \\
\text { equitation }\end{array}$ \\
\hline $\begin{array}{l}\text { Claver, Rienda } \\
\text { \& Quer (2007) }\end{array}$ & $x$ & & & Spain & & $\mathrm{x}$ & 2004 & $x$ & & 6 & - & various & SM & $x$ & $x$ & & & $\mathrm{~N} / \mathrm{A}$ & qualitative \\
\hline Pinho (2007) & & & $X$ & Portugal & $x$ & $\mathrm{x}$ & N/A & $x$ & & $600+7$ & 14.5 & various & SM & $\begin{array}{c}\mathrm{N} / \\
\mathrm{A}\end{array}$ & & & & executives & regression \\
\hline $\begin{array}{l}\text { Claver, Rienda } \\
\text { \& Quer (2008) }\end{array}$ & & & $X$ & Spain & $x$ & & $\mathrm{~N} / \mathrm{A}$ & $x$ & & 2000 & 7 & various & SML & $x$ & $x$ & & & executives & regression \\
\hline $\begin{array}{l}\text { Graves \& } \\
\text { Thomas (2008) }\end{array}$ & $x$ & & & Australia & & $x$ & $\begin{array}{l}2003- \\
2004\end{array}$ & & $x$ & 8 & - & manufact & SM & $x$ & $x$ & & & $\begin{array}{l}\text { senior } \\
\text { managers }\end{array}$ & Nvivo \\
\hline
\end{tabular}

Table 2. Methodological and definitional issues in the articles reviewed.

$S=$ small, $M=$ medium-sized, $L=$ large 
Type of research. Regarding the type of research, we organized the articles within three groups: exploratory, descriptive, and confirmatory. The confirmatory group (where the aim was to statistically verify theory-driven hypotheses) consisted of 12 articles. A further 10 articles were placed in the group of exploratory studies. The group of descriptive studies (offering a quantitative assessment of the phenomenon by providing data on prevalence, frequency or intensity) comprised only 3 studies. Hence it would seem that FB internationalization research is dominated by (i) studies with theorydriven hypotheses, and (ii) exploratory studies.

Country of research and data collection. The data for analyzing FB internationalization were collected between 1994 and 2004 from 8 different countries, 5 of these countries being situated in Europe. Data were collected more than once in Spain (6 databases), China (3 databases), Australia (2 databases), and the USA ( 2 databases). Hence, the geographical coverage was fairly wide, but the number of studies in any given continent was low. The most common data collection method was by survey: in fact, there were 13 articles based purely on surveys, but in a further 3 articles a survey was used in addition to a case study approach. Hence, there were in all 7 articles which employed a case study approach. In addition, there was one conceptual article.

Given that FB internationalization is a very young field with only limited knowledge available, we would recommend a more exhaustive use of the case study approach. It makes possible an in-depth investigation and explanation of cause-andeffect relationships, and also the application of replication logic, in such a way that researchers can identify the subtle similarities and differences across a collection of cases (Eisenhardt, 1989; Yin, 1994). It also makes it possible to set up propositions for further quantitative testing.

Time frame, sample size and response rate. There were five longitudinal databases, but the majority of articles used cross-sectional data. The dominance of cross-sectional databases could have meant that overall, researchers were provided with somewhat superficial information. Longitudinal studies will be needed in the future, since they will show the process of internationalization as it occurs over time. The survey sample sizes ranged between 222 and 2455 firms $^{2}$. In the articles based on case study research, the number of cases ranged from one to ten cases. In the 6 articles utilizing secondary survey data (indicated by an asterisk in Table 2), the response rate exceeded $90 \%$. In the remaining surveys, the usable response rate was rather low, between $7 \%$ and $37.4 \%$. We would recommend the use of personally administrated surveys: such a method would definitely increase the response rate.

Industry type and firm size. Manufacturing companies were studied in 12 articles and firms from a broader range of industries in 10 articles. This would suggest that studies concentrating on specific (non-manufacturing) industries are needed, on the grounds that there may be differences between manufacturing and service industries (O’Farrell, Wood, \& Zheng, 1997), and between high-tech and low-tech firms (Bell et al.,

\footnotetext{
${ }^{2}$ Random sampling was executed in 5 of the research articles analyzed. There were 5 studies with purposive sampling. Explicit criteria for sample selection could be discovered in 18 studies. Firm size was the most common criterion (8 articles), followed by sector (7 articles), ownership (5 articles), and international involvement (4 articles).
} 
2004). As for the size of the FBs, the majority of the studies (14 articles) were based on small and medium-sized enterprises (SMEs), 4 articles concentrated on large family firms, and 4 articles assessed family firms of all sizes.

Family firm definition. There was no general consensus on the definition of a "family firm". We classified the articles according to the most common criteria applied in the articles, namely ownership, management, continuity, and subjective perception. The most common way of defining a family firm (12 articles) was through a combination of ownership and management criteria, in line with Gallo and Sveen (1991). According to the definition applied in this case, a family firm is "a firm where the family owns the majority of stock and exercises full managerial control" (Gallo \& Sveen, 1991, 182). In some articles, the continuity ${ }^{3}$ criterion or the subjective perception criterion was added to ownership and management. In 4 articles, surprisingly, no definition of a family firm could be found. In further research, it will be necessary to improve and unify the definition of a family firm, so that FB research can be made more understandable and comparable. In some circumstances, it may also be relevant to divide firms into more than the two groups (FBs vs. non-FBs) generally used in articles up to now. The division of firms according to their position on a continuum, based on differing degrees of ownership, managerial influence and continuity, could enrich our understanding of FB internationalization. Such a division is also recommended by Sharma (2004).

Informants. In 11 articles, the interviewees were identified as executives or managers, while in 2 articles they were identified as an owner or owner-manager. This indicates that in 12 articles, the key informants were not identified. In further studies, for the sake of validity, more attention will have to be given to the systematic reporting of key informants. In addition, by using two or more informants from each firm, researchers should be able to offset biases based on individual opinions (Huber \& Power, 1985). This means that the range of key informants could be extended from ownermanagers to other family members, to other executive board members, and to staff personally involved in the internationalization process.

Analytical approach. The dominant analytical approach was some form of regression analysis (8 studies) followed by structural equation modeling (3 studies), general descriptive statistics (2 studies), probit and tobit data models (2 studies) and Utests (one study). Thus, the analytical approaches were fairly sophisticated. By comparison, the analytical approaches of the qualitative case studies were rather poorly reported - with the exception of one article (Yeung, 2000) reporting the usage of a grounded theory approach, and 2 other qualitative articles (Claver et al., 2007; Graves \& Thomas, 2008) in which the methodology was described fairly well. Overall, due to inaccuracies or a lack of clarity, doubt might be cast on the validity of the articles

\footnotetext{
${ }^{3}$ Casillas and Acedo (2005) created 4 groups, based on their own FB definition involving ownership, management, and continuity: 1) non-family firms, 2) firms with little family involvement, 3) firms with quite a lot of family involvement, and 4) absolute family firms. In contrast, Tsang (2002) divided the case firms into FBs, semi-FBs (possessing only some of the characteristics of a typical FB), and non-FBs. Nonetheless, no precise criteria for these different categories were found.
} 
reviewed. In further studies, attention ought to be paid to reporting the analytical approaches more systematically.

\subsection{Theoretical frameworks utilized in the articles reviewed}

Only 8 of the articles were mainly based on internationalization theories. Table 3 presents the internationalization theories used in the reviewed articles, with a summary for each article. In 4 of the studies the process model of internationalization (also known as the Uppsala model) was applied. Dunning's eclectic paradigm was used in 3 research articles. The resource-based view of internationalization was utilized in one study focusing on managerial capabilities. Interestingly, the network theory of internationalization was utilized in only one study, and even there, it was handled on a very general level along with other theories. It is true that that most of the articles did give a brief introduction to internationalization, even if they did not utilize internationalization theories as such in their frameworks. Nevertheless, from the material in general it appeared that the integration of various internationalization theories - something that has been recommended by several researchers (e.g. Coviello \& McAuley, 1999) - was limited, since only Graves and Thomas (2004) clearly indicated the use of different internationalization theories. There is a need for studies which would take a more holistic view, given the complexity of the process of internationalization (see e.g. Bell, McNaughton, Young, \& Crick, 2003; Johanson \& Vahlne, 2003).

\begin{tabular}{|c|c|c|}
\hline $\begin{array}{l}\text { Internationalization } \\
\text { theory }\end{array}$ & Description & $\begin{array}{l}\text { Usage in } \quad \text { FB } \\
\text { internationalization studies }\end{array}$ \\
\hline $\begin{array}{l}\text { Process model of } \\
\text { internationalization } \\
\text { (Uppsala Model); } \\
\text { (Johanson \& Vahlne, } \\
\text { 1977) }\end{array}$ & $\begin{array}{l}\text { Describes internationalization as an } \\
\text { incrementally evolving process, in } \\
\text { which a firm internationalizes its } \\
\text { operations by going through } \\
\text { various stages. }\end{array}$ & $\begin{array}{l}\text { - Graves \& Thomas, 2004, } 2008 \\
\text { - Claver et al., } 2007 \\
\text { - Casillas \& Acedo, } 2005\end{array}$ \\
\hline $\begin{array}{l}\text { Network model of } \\
\text { internationalization; } \\
\text { (Johanson \& Mattsson, } \\
\text { 1988) }\end{array}$ & $\begin{array}{l}\text { The internationalization of firms is } \\
\text { explained with reference to the } \\
\text { networks the utilize. }\end{array}$ & $\begin{array}{l}\text { - Graves \& Thomas, } 2004 \text { (to a } \\
\text { limited extent) }\end{array}$ \\
\hline $\begin{array}{l}\text { Resource-based view; } \\
\text { (Barney, 1991) }\end{array}$ & $\begin{array}{l}\text { Decisions are made within a } \\
\text { coordinated framework of } \\
\text { resources, capabilities and } \\
\text { environmental contingencies. }\end{array}$ & $\begin{array}{l}\text { - Graves \& Thomas, } 2006 \\
\text { (managerial capabilities) }\end{array}$ \\
\hline $\begin{array}{l}\text { Dunning's eclectic } \\
\text { paradigm; } \\
\text { (Dunning, 1980) }\end{array}$ & $\begin{array}{l}\text { Describes the internationalization of } \\
\text { firms in terms of OLI-advantages: } \\
\text { ownership, location, and } \\
\text { internalization }\end{array}$ & $\begin{array}{l}\text { - Erdener \& Shapiro, } 2005 \\
\text { - Pinho, } 2007 \\
\text { - George et al., } 2005\end{array}$ \\
\hline
\end{tabular}

Table 3. Internationalization theories and their application in the studies reviewed. 
In the articles that did not apply internationalization theories, the most generally used theories were ownership theory ${ }^{4}(5$ articles) and agency theory ( 2 articles). The other theories used (one article each) were managerial capabilities theory, entrepreneurial orientation theory, theory concerning entrepreneurs' characteristics and attributes, and organizational learning theory. In 3 articles, no specific background theory was utilized. All in all, it appeared that combinations of several theories (or viewpoints within theoretical frameworks), other than internationalization theories, dominated the studies on FB internationalization. This can be seen as a positive feature, one that can lead to expansionary development of the field. However, it also makes the study of FB internationalization very fragmented, and the comparison of findings more difficult.

Overall, the formation and the justification of the theoretical frameworks utilized tended to be somewhat ambiguous: there was a lack of a clear account of the theories that were seen as most important, and there was often no indication of whether the framework applied was based on "theories" or perspectives. Furthermore, the theory tended to be inadequately applied in the actual analysis of the data.

\subsection{The findings reported in the articles}

The articles were categorized within three groups ${ }^{5}$ according to their subject matter, namely: the internationalization process (5 articles), managerial/strategic issues (11 articles), and factors influencing FB internationalization (11 articles). Table 4 below presents the articles together with the category they belong to, plus a summary of the findings of the article in question.

\footnotetext{
${ }^{4}$ Several authors called "the ownership view", indicating that they assessed the effect of ownership on internationalization, a theory in their article, but it is better regarded merely as a viewpoint.

${ }^{5}$ It should be noted that two of the articles examined issues relating to two of these categories; hence they are listed as belonging to both categories.
} 


\begin{tabular}{|c|c|c|c|c|}
\hline $\begin{array}{l}\text { No } \\
\text {. }\end{array}$ & Year & $\begin{array}{l}\text { Author(s) / } \\
\text { Journal }\end{array}$ & Topic of the article & Main findings \\
\hline 1 & 1991 & $\begin{array}{l}\text { Gallo \& Sveen } \\
\text { FBR }\end{array}$ & $\begin{array}{l}\text { Factors influencing FB } \\
\text { internationalization }\end{array}$ & $\begin{array}{l}\text { The restricting factors in FB internationalization are mainly organizational; they include unwillingness to } \\
\text { accept outside expertise, difficulties in hiring new managers with international responsibility, a fear of losing } \\
\text { control, and poorly developed information and control systems. }\end{array}$ \\
\hline 2 & 1993 & $\begin{array}{l}\text { Svinth \& } \\
\text { Vinton } \\
\text { FBR }\end{array}$ & Managerial/strategic issues & $\begin{array}{l}\text { International joint ventures between FBs are more likely to succeed than those between FBs and non-FBs; } \\
\text { this is explained by similar values (even across cultures), including trust, loyalty, and continuation of the } \\
\text { family. }\end{array}$ \\
\hline 3 & 1996 & $\begin{array}{l}\text { Gallo \& Pont } \\
\text { FBR }\end{array}$ & $\begin{array}{l}\text { Factors influencing FB } \\
\text { internationalization }\end{array}$ & $\begin{array}{l}\text { Restricting factors in FB internationalization include: product orientation to the domestic customer, a lack of } \\
\text { financial resources or family members prepared for internationalization, resistance of the management team } \\
\text { towards internationalization, an unwillingness to form alliances, intra-firm power struggles. Facilitating } \\
\text { factors include: the possibility for work opportunities for other family members through } \\
\text { internationalization, members of the family residing in various countries, a general long-term orientation, } \\
\text { speed in decision-making, and the possibility of alliances with other FBs. Non-leading FBs orient themselves } \\
\text { more toward international markets. }\end{array}$ \\
\hline 4 & 1999 & $\begin{array}{l}\text { Okoroafo } \\
\text { FBR }\end{array}$ & $\begin{array}{l}\text { Factors influencing FB } \\
\text { internationalization }\end{array}$ & $\begin{array}{l}\text { FBs monitor the international environment irregularly, and do not integrate global developments within } \\
\text { their domestic decisions. If a family firm does not get involved in international business in the first or second } \\
\text { generation, it is unlikely to do so in the third generation. In addition to exporting, FBs form joint ventures. }\end{array}$ \\
\hline 5 & 2000 & $\begin{array}{l}\text { Davis \& } \\
\text { Harveston } \\
\text { FBR }\end{array}$ & $\begin{array}{l}\text { Factors influencing FB } \\
\text { internationalization }\end{array}$ & $\begin{array}{l}\text { Internet usage and investments in information technology have a positive influence on the } \\
\text { internationalization and organizational growth of FBs. }\end{array}$ \\
\hline 6 & 2000 & $\begin{array}{l}\text { Yeung } \\
\text { FBR }\end{array}$ & $\begin{array}{l}\text { Factors influencing FB } \\
\text { internationalization }\end{array}$ & $\begin{array}{l}\text { The influence of paternalism, nepotism, personalism, and fragmentation in Chinese FBs is less relevant if the } \\
\text { firm acts regionally or globally. }\end{array}$ \\
\hline 7 & 2001 & $\begin{array}{l}\text { Tsang } \\
\text { JSBM }\end{array}$ & Internationalization process & $\begin{array}{l}\text { The founder has a heavy involvement in establishing international operations and wants to have total } \\
\text { control of everything. The role of intuition in decision-making is crucial. }\end{array}$ \\
\hline $8^{*}$ & 2002 & $\begin{array}{l}\text { Tsang } \\
\text { JBV }\end{array}$ & Internationalization process & $\begin{array}{l}\text { In the foreign direct investment process, FBs have a less formal and structured way of collecting information } \\
\text { and conducting analyses than non-FBs; semi-FBs are situated somewhere in between these two. }\end{array}$ \\
\hline 9 & 2002 & $\begin{array}{l}\text { Child, } \mathrm{Ng} \& \\
\text { Wong } \\
\text { ISMO }\end{array}$ & Internationalization process & FBs move stepwise from psychically close to psychically more distant destinations. \\
\hline $10^{*}$ & 2003 & $\begin{array}{l}\text { Zahra } \\
\text { JBV }\end{array}$ & Managerial/strategic issues & $\begin{array}{l}\text { FB owner-managers maximize revenues from certain foreign markets rather than aggressively pursue } \\
\text { internationalization into several markets }\end{array}$ \\
\hline $11^{*}$ & 2004 & $\begin{array}{l}\text { Graves \& } \\
\text { Thomas } \\
\text { IJGSB }\end{array}$ & Managerial/strategic issues & $\begin{array}{l}\text { FBs are less likely to internationalize than non-FBs; family firms are less likely to engage in networking with } \\
\text { other businesses. }\end{array}$ \\
\hline 12 & 2005 & $\begin{array}{l}\text { Casillas \& } \\
\text { Acedo } \\
\text { IJGSB }\end{array}$ & $\begin{array}{l}\text { Factors influencing FB } \\
\text { internationalization }\end{array}$ & $\begin{array}{l}\text { The higher the perception of risks, the lower the firm's internationalization level. The older the firm, the } \\
\text { larger its size, and the higher its internationalization level. }\end{array}$ \\
\hline
\end{tabular}




\begin{tabular}{|c|c|c|c|c|}
\hline $13^{*}$ & 2005 & $\begin{array}{l}\text { Erdener \& } \\
\text { Shapiro } \\
\text { MOR }\end{array}$ & Managerial/strategic issues & $\begin{array}{l}\text { Concerning OLI (ownership, location, internalization) advantages, the international Chinese family } \\
\text { enterprise is analytically distinct from other kinds of firms. }\end{array}$ \\
\hline $14^{*}$ & 2005 & $\begin{array}{l}\text { Fernández \& } \\
\text { Nieto } \\
\text { FBR }\end{array}$ & $\begin{array}{l}\text { Factors influencing FB } \\
\text { internationalization }\end{array}$ & $\begin{array}{l}\text { The arrival of new generations has a positive influence on the internationalization of family firms; FBs are } \\
\text { less likely to internationalize than non-FBs. }\end{array}$ \\
\hline 15 & 2005 & $\begin{array}{l}\text { George, } \\
\text { Wiklund \& } \\
\text { Zahra } \\
\text { JOM }\end{array}$ & $\begin{array}{l}\text { Factors influencing FB } \\
\text { internationalization }\end{array}$ & $\begin{array}{l}\text { Institutional and VC ownership increase the scale of SME internationalization, indicating the important role } \\
\text { these investors play in firms of this kind. On the other hand, CEO and top management team management } \\
\text { increase managerial risk aversion, and also the scope and scale of internationalization. }\end{array}$ \\
\hline $16^{*}$ & 2005 & $\begin{array}{l}\text { Menéndez- } \\
\text { Requejo } \\
\text { IJGSB }\end{array}$ & $\begin{array}{l}\text { Factors influencing FB } \\
\text { internationalization }\end{array}$ & New generations have a positive influence on the internationalization of family firms. \\
\hline $17^{*}$ & 2005 & $\begin{array}{l}\text { Thomas \& } \\
\text { Graves } \\
\text { JBE }\end{array}$ & $\begin{array}{l}\text { Managerial/strategic issues } \\
\text { AND Factors influencing FB } \\
\text { internationalization }\end{array}$ & $\begin{array}{l}\text { Unless family business managers have the freedom to act autonomously, the ability to benefit internationally } \\
\text { from such innovation capability may be limited; FB owners do not borrow from external sources to facilitate } \\
\text { internationalization; the decision to internationalize was found to be taken for longer-term strategic reasons. }\end{array}$ \\
\hline $18^{*}$ & 2006 & $\begin{array}{l}\text { Crick, } \\
\text { Bradshaw \& } \\
\text { Chaudry } \\
\text { JSBED }\end{array}$ & Managerial/strategic issues & $\begin{array}{l}\text { Family SMEs and non-family SMEs did not develop very different bundles of resources in order to be } \\
\text { internationally successful. }\end{array}$ \\
\hline $19^{*}$ & 2006 & $\begin{array}{l}\text { Fernández \& } \\
\text { Nieto } \\
\text { JIBS }\end{array}$ & Managerial/strategic issues & $\begin{array}{l}\text { FBs have difficulties in building a portfolio of strategic resources, and this makes international success more } \\
\text { difficult for them. Ownership by corporate shareholders was a positive indicator for the scale of family SME } \\
\text { internationalization. }\end{array}$ \\
\hline $20^{*}$ & 2006 & $\begin{array}{l}\text { Graves \& } \\
\text { Thomas } \\
\text { FBR }\end{array}$ & Managerial/strategic issues & The managerial capabilities of family SMEs lag behind those of their non-family counterparts. \\
\hline $21^{*}$ & 2007 & $\begin{array}{l}\text { Basly } \\
\text { BJM }\end{array}$ & Managerial/strategic issues & Networking has a positive effect on the amount of internationalization knowledge among family SMEs. \\
\hline 22 & 2007 & $\begin{array}{l}\text { Claver, } \\
\text { Rienda \& } \\
\text { Quer } \\
\text { JGM }\end{array}$ & Internationalization process & $\begin{array}{l}\text { FBs follow the propositions laid down by the Uppsala model of internationalization. Nonetheless, the phases } \\
\text { of experimental exports and joint ventures were added to the Uppsala model of internationalization }\end{array}$ \\
\hline $23^{*}$ & 2007 & $\begin{array}{l}\text { Pinho } \\
\text { IMR }\end{array}$ & Managerial/strategic issues & $\begin{array}{l}\text { FBs do not differ from non-FBs in their operational modes: they do not prefer indirect entry modes to direct } \\
\text { entry modes. }\end{array}$ \\
\hline $24^{*}$ & 2008 & $\begin{array}{l}\text { Claver, } \\
\text { Rienda \& } \\
\text { Quer } \\
\text { JSBED }\end{array}$ & Managerial/strategic issues & FBs experienced the risks connected to internationalization more strongly than non-FBs. \\
\hline 25 & 2008 & $\begin{array}{l}\text { Graves \& } \\
\text { Thomas } \\
\text { FBR }\end{array}$ & $\begin{array}{l}\text { Internationalization process } \\
\text { AND Factors influencing FB } \\
\text { internationalization }\end{array}$ & $\begin{array}{l}\text { Most family SMEs internationalize according to the Uppsala model, but some of them internationalize } \\
\text { rapidly, regarded as born-again global firms, for instance in the context of succession. The three key } \\
\text { determinants for the internationalization of FBs were the level of commitment toward internationalization, } \\
\text { the financial resources available, and the ability to commit and use those financial resources to develop the } \\
\text { required capabilities. }\end{array}$ \\
\hline
\end{tabular}


The internationalization process. In this group of articles (only 5 articles) FBs were seen as following the propositions laid down in the Uppsala model of internationalization: they internationalize sequentially, and they usually launch their internationalization process in countries that are close from a geographical or cultural point of view. Nonetheless, it was observed that some family SMEs internationalize rapidly to several countries after the reins are taken up by the next generation; these firms can be termed "born-again globals". In their foreign direct investment, FBs were seen has having a less formal or structured way of collecting information and conducting analysis than non-FBs. But all in all, what emerged was how little knowledge of the internationalization processes of FBs actually exists, suggesting that a great deal of verification (both qualitative and quantitative) is needed.

Managerial and strategic issues. Most of the articles in this group claimed that the propensity to internationalization is lower among FBs than among non-FBs; however, one study found no difference in the propensity. Strategically, FBs were perceived as monitoring the international environment irregularly, and paying very little attention to global developments in their domestic decisions. The FB owner-managers studied were likely to seek to maximize revenues from particular foreign markets that they were acquainted with, rather than pursue internationalization aggressively across several markets. Furthermore, FB owners did not borrow from external sources to facilitate their outside expansion, and any decision to internationalize was taken for longer-term strategic reasons. The managerial capabilities of family entrepreneurs were found to be poorer than those of non-family managers: except in cases where FB managers had the freedom to act autonomously, they did not display much of the innovation capability that would enable them to expand internationally. More generally, FBs were claimed to have difficulties in building a portfolio of strategic resources, and this, too, was something that made it more difficult for them to succeed internationally. Ownership by outside (non-family) shareholders was seen as a positive indicator for the scale of family SME internationalization. From the perspective of networking, FBs did not form networks as easily as non-FBs.

Altogether, a number of views emerged relating to managerial and strategic issues in the context of the internationalization of family-owned firms. However, all these findings need further verification, and also new investigative approaches (which will be discussed more in detail in section 4 of this article). What one can say is that studies describing the management processes of family firms in the context of internationalization were almost non-existent.

Factors influencing FB internationalization. The articles examining this aspect mainly aimed at laying a foundation for FB internationalization considered as a subfield for research. Their main findings suggest that the factors inhibiting FB internationalization are mainly organizational: they include an unwillingness to accept outside expertise, a fear of losing control, risk avoidance, and a lack of financial resources. The factors enhancing the internationalization of family firms include a general long-term orientation, and speed in decision-making. In addition, it was found that the FBs that are likely to be more successful in international expansion are those 
that have a willingness to use information technology, a capability for innovation, and a commitment to internationalization, plus the ability to distribute power and use the resources that are available. Generally speaking, the entry on the scene of new generations was seen as having a positive influence on internationalization, although generational change sometimes had no influence, or else had a negative influence on internationalization. 


\section{Directions for further research}

Based on the review, it can be stated with certainty that the body of knowledge on FB internationalization is narrow. The actual number of articles is small. Furthermore, many of the studies that have been carried out are descriptive by nature, going no further than laying the foundations for the research sub-field of FB internationalization. Table 5 below, which is derived from the present study, summarizes the overall situation, i.e. where the field is now, and where it might go. Thus we have four broad topic areas in column 1 of the table, namely: (i) the internationalization process, (ii) managerial and strategic issues, (iii) factors influencing FB internationalization, and (iv) methodology. Column 2, which is based on the 25 reviewed articles, summarizes the state of current knowledge. Column 3 presents the research issues that are important in developing the sub-field of FB internationalization. The future issues identified are based on the gaps between the knowledge found in the articles within this review, and the knowledge one might aim at in the research fields of international business (see e.g. Acedo \& Casillas, 2005; Knight \& Kim, 2009;), international entrepreneurship (see e.g. Coviello \& Jones, 2004; Coviello \& McAuley, 1999; Dimitratos \& Jones, 2005; Keupp \& Gassmann, 2009), and family business (see e.g. Carney, 2005; Chrisman, Steier \& Chua 2006; Sharma, 2005; Sirmon \& Hitt, 2003; Zahra \& Sharma, 2004). Below, we shall consider the topic areas in column 1 individually. 


\begin{tabular}{|c|c|c|}
\hline Topic area & Current knowledge & $\begin{array}{l}\text { Future research needs in FB } \\
\text { studies }\end{array}$ \\
\hline $\begin{array}{l}\text { (i) The } \\
\text { internationalization } \\
\text { process }\end{array}$ & $\begin{array}{l}\text { - Incremental } \\
\text { - Follows mainly the Uppsala } \\
\text { model } \\
\text { - Some FBs are "born-again } \\
\text { global firms" } \\
\text { - FBs have limited networks }\end{array}$ & $\begin{array}{l}\text { - Formation and development of } \\
\text { network ties / social capital in } \\
\text { internationalization } \\
\text { - Verification of the Uppsala } \\
\text { model of internationalization } \\
\text { - Effect of succession on the } \\
\text { internationalization process } \\
\text { - Foreign market entry directed } \\
\text { at a particular target market }\end{array}$ \\
\hline $\begin{array}{l}\text { (ii) Managerial and } \\
\text { strategic issues } \\
\text { among FBs }\end{array}$ & $\begin{array}{l}\text { - Domestic perspective } \\
\text { - Risk-avoiding strategies } \\
\text { - Not aggressively pursuing } \\
\text { internationalization across } \\
\text { several markets } \\
\text { - Outside shareholders have a } \\
\text { positive effect on the scale of } \\
\text { internationalization } \\
\text { - Limited managerial } \\
\text { capabilities } \\
\text { - Management of } \\
\text { internationalization processes } \\
\text { unstructured }\end{array}$ & $\begin{array}{l}\text { - Foreign market and entry } \\
\text { mode selection } \\
\text { - International opportunity } \\
\text { recognition } \\
\text { - Effects of parsimony, } \\
\text { personalism, and particularism } \\
\text { - Decision-making through } \\
\text { "socioemotional-wealth"- } \\
\text { perspective }\end{array}$ \\
\hline $\begin{array}{l}\text { (iii) Factors } \\
\text { influencing FB } \\
\text { internationalization }\end{array}$ & $\begin{array}{l}\text { - Limited financial capital } \\
\text { - Long-term plans } \\
\text { - Possibility to take quick } \\
\text { decisions } \\
\text { - Fear of losing control in the } \\
\text { context of internationalization }\end{array}$ & $\begin{array}{l}\text { - Effects of FB-specific } \\
\text { resources: human capital, } \\
\text { social capital, survivability } \\
\text { capital, patient capital and } \\
\text { governance structures } \\
\text { - Effect of internationalization } \\
\text { on the family firm, financial } \\
\text { performance, and family unit }\end{array}$ \\
\hline (iv) Methodology & $\begin{array}{l}\text { - Existing research mainly } \\
\text { answers what-questions } \\
\text { - Focus on manufacturing } \\
\text { sector } \\
\text { - Inadequate reporting } \\
\text { - FB definition most often } \\
\text { based on ownership and } \\
\text { management }\end{array}$ & $\begin{array}{l}\text { - Answers to how and why } \\
\text { questions; case studies } \\
\text { - Studies on service, high and } \\
\text { low technology FBs } \\
\text { - More accurate reporting } \\
\text { - More extensive use of } \\
\text { informants } \\
\text { - More coherent FB definition } \\
\text { or usage of this concept's }\end{array}$ \\
\hline
\end{tabular}


potential to describe different FBs

Table 5. Current knowledge and further directions for research.

(i) The internationalization process. The 5 studies examining FB internationalization from the perspective of the internationalization process indicated that the internationalization of FBs is incremental and mainly follows the Uppsala model of internationalization; by contrast, some FBs were regarded as "born-again" global firms. Concerning networks, the only fact revealed in the studies is that the networks are limited. This means that there is a significant research gap concerning FB networks in the process of internationalization, bearing in mind that in research on other kinds of firms, networks have been extensively studied (see e.g. Coviello \& McAuley, 1999). As a first main recommendation, we would suggest that the network theory of internationalization (Johanson \& Mattsson, 1988) could provide valuable insights on the network dynamics of FB internationalization. It could clarify the kinds of networks FBs use when they internationalize (involving e.g. the role of family ties), and how these networks evolve during internationalization. Miller, Le Breton-Miller and Scholnick (2008) have noted that family firms are different from non-family firms in the sense that in FBs the community of employees is nurtured very carefully, and closer connections with customers are sought in order to sustain the business. In the international arena, the nurturing of these aspects could prove especially demanding, since the cooperating partners are culturally and psychologically different, and often also geographically far away. On the other hand, such nurturing could lead to especially good international relationships once trust has been established. Family/social capital theory (e.g. Adler \& Kwon, 2002) is another alternative that could help us to understand networks and their nature (including, for instance, the role of trust) in this context. It has been suggested that social capital is particularly abundant among family-owned businesses, because of the unification of ownership and management (Salvato \& Melin 2008). Indeed, the inner bonding aspect of social capital among family firms is a well-researched topic (see e.g. Arregle, Hitt, Sirmon \& Very 2007; Salvato \& Melin 2008), but the workings of bridging social capital in such firms remains an under-researched topic (Graves \& Thomas, 2004). Bridging social capital occupies a particularly important place in internationalization; hence it should receive the attention of scholars.

As a second recommendation, bearing in mind the limited number of studies conducted and the focus on the general internationalization pattern, we would suggest that the Uppsala model of internationalization (Johanson \& Vahlne, 1977; Johanson \& Wiedersheim-Paul, 1975) should be more extensively utilized, applying it to differing cultural contexts, since it can be assumed that family firms will follow the Uppsala model of internationalization because of their risk-averse strategies (Claver et al., 2008; George et al., 2005). Thirdly, the effect of generational change on the internationalization of FBs ought to be studied in more detail. From earlier studies it appears that succession can accelerate, slow down, or have no effect on the internationalization of FBs (Fernanzed \& Nieto, 2005; Graves \& Thomas, 2008). To understand this issue, we would 
recommend use of International New Venture theory (Oviatt \& McDougall, 1994) in attempting to explain the behavior of FB "born-again global" firms (Bell, McNaughton \& Young, 2001; Graves \& Thomas, 2008). This could also lead to a better understanding of the speed of internationalization, given that some FBs internationalize very quickly after operating for a long time in the domestic market (see e.g. Bell et al., 2001; Graves \& Thomas, 2008). Fourthly, very limited knowledge is available on the internationalization processes of FBs that are directed at particular target markets. As was mentioned above, previous FB studies have concentrated solely on the general pattern of internationalization. Thus there is little knowledge of the ways in which FBs cope with cultural and psychological differences in their foreign market entries. Studies on this aspect should be conducted, bearing in mind that because of the limited financial capital, risk avoidance, and long term commitment of FBs, this process can be assumed to be different from that among, for example, knowledge-intense SMEs (see e.g. Ojala, 2008).

(ii) Managerial and strategic issues. According to the articles, the scale of internationalization among FBs is typically influenced by domestic perspectives, by riskavoidance strategies, by non-aggressive internationalization into several markets, and (positively) by outside shareholders. Furthermore, FB managers are seen as having limited managerial capabilities and as conducting unstructured procurement in the context of internationalization. Because knowledge of the strategies in question appears at present to be on a general level, we would suggest that, in the future, researchers should take fully into account the kinds of major strategic decisions regarding internationalization that have been extensively studied in international business and international entrepreneurship. Based on the general strategic differences between FBs and firms with other ownership structures, one may hypothesize that there will be differences also in foreign market selection compared to other kinds of firms (see e.g. Davidson, 1983; Ojala \& Tyrväinen, 2007). For instance, FB risk-avoidance strategies would lead one to expect that FBs will favor countries that are culturally and geographically close, and will select low-commitment operation modes (see e.g. Johanson \& Vahlne, 1977; Kumar \& Subramaniam, 1997). Related to market selection, it would be important to discover whether FBs strategically select particular foreign markets, or whether they just follow up opportunities that happen to emerge. Such a possibility arises from e.g. the study by Graves and Thomas (2008), which indicated that FBs may be more reactive than proactive when they recognize opportunities for internationalization. ${ }^{6}$ This is connected to another important potential research area concerning managerial and strategic issues in the internationalization of FBs, namely international opportunity recognition, which is an essential phase of internationalization (Dimitratos \& Jones, 2005; Ellis, 2008; Zahra, Korri \& Yu, 2005). The opportunity recognition of FBs may well be different from that of other kinds of firm, since they have limited networks (Graves \& Thomas, 2004) and lack financial resources (Gallo \& Pont, 1991).

\footnotetext{
${ }^{6}$ Compare Ojala (2009), who studied the proactivity of software firms in foreign market entry.
} 
Thirdly, to get a more profound understanding of the special features of FB management in the context of internationalization, we would recommend studies on FBspecific management aspects. For instance, three characteristics have been identified in the family form of governance, namely parsimony, personalism, and particularism (see Carney, 2005). Parsimony refers to the propensity of family firms to carefully manage resources, due to the fact that the family owns these resources. This might indicate for instance a cautious attitude and slow progress in internationalization. Personalism comes from the intertwining of ownership and control, all held within one family. Compared with non-family firms, this concentration of power frees family firms from the need to account for their actions to other internal and external constituencies, giving them the discretion to make decisions on their own. Hence, family firms can proceed with internationalization in the way they like, in contrast to, for instance, venture capital firms (Johanson \& Vahlne, 2009). Particularism is the outcome of this discretion.

All this adds up to the ability of family firms to employ idiosyncratic criteria and to set goals that deviate from the typical profit-maximization concerns of nonfamily firms. For instance, internationalization may be directed to certain target markets of interest to the family, and if there is the determination to guarantee the maximum amount of control for the family, the firm can utilize high-control operation modes. Alternatively, features of strategic decision-making in the internationalization of FBs could be understood and explained through the "socioemotional wealth" perspective proposed by Gomez-Mejia, Makri and Kintana (2010). They claim that the will to guarantee the socioemotional wealth of the FB always comes first in FB strategic decision-making. This could indicate, for instance, either high or limited financial risktaking and a low or high level of diversification, depending on the extent to which the well-being of the staff can be guaranteed. In turn, these aspects could affect, for instance, the propensity for and speed of internationalization, the countries entered, and the operation modes selected.

(iii) Factors influencing FB internationalization. Based on existing literature, the factors affecting the internationalization of FBs appear to include long-term plans, the possibility to take quick decisions, and the fear of losing control following internationalization. Furthermore, FBs have been seen as having limited financial resources. Studies are needed, first of all, on the resources used by FBs to compensate for their lack of financial resources during internationalization - for instance studies utilizing the resource-based view (Barney, 1991).

With a view to going more deeply into family firm-specific issues, one can, for instance, point to the research of Sirmon and Hitt (2003), who suggested five unique characteristics that can differentiate family firms from non-family firms, namely human capital, social capital, survivability capital, patient capital, and governance structures. These five unique resources (which are found in family firms but not in non-family firms) may - if linked to good management capabilities - contribute to wealth creation, with endeavors aimed at international expansion. The positive attributes of human capital include extraordinary commitment, warm, friendly, and intimate relationships, and the potential for deep firm-specific tacit knowledge. On the other hand, the limited 
utilization of outside managers by family firms has the potential to hinder their wealth creation (Sirmon \& Hitt, 2003). Family firms are also based on strong social capital: they have shared language and narratives, norms, obligations, and a high level of trust. On this foundation, the firm can build more effective relationships with suppliers, customers, and support organizations. The patient financial capital of family firms in based on their long-term orientation: money is invested for long periods. The disadvantage of patient financial capital is the limited amount of external financial capital, due to unwillingness to share equity with non-family members. Survivability capital is related to the pooled personal resources that family members are willing to lend, contribute, or share for the benefit of the firm. Concerning governance structures, family firms generally enjoy lower governance costs, and this can be a competitive advantage. Nonetheless, the agency costs of family firms may tend to increase dramatically due to the owner/manager's altruism (Sirmon \& Hitt, 2003). A focus on these FB-specific features would help to clarify the special traits and resources of FBs in the context of internationalization. They could affect internationalization, for example, via the ways in which FBs look for especially trustful relationships with in-depth industry-specific knowledge, internationalize incrementally with a high degree of patience, and utilize unstructured decision-making. In addition, the FBs may be willing to utilize the financial resources of the family for internationalization, for instance during poor economic times. In further research, both the positive and the negative influences of the factors above ought to be considered. Further studies are also needed to reveal the effects that internationalization can have on a FB, other than growth and survival, including the effects that internationalization can have on the financial performance of the FB. These are important features that have been neglected in existing studies.

In conclusion, among the factors affecting FB internationalization, there is an obvious need to the study the institution of the family itself - an aspect hitherto ignored in studies on FB internationalization. It would be important to discover how internationalization affects the family unit and its relationships, since internationalization always has the potential to disturb the historical harmony of the firm. Furthermore, it would be of interest to determine the role that may be played by differing degrees of family ownership and/or management, and by continuity - issues highlighted by for instance Tsang (2001) and by Graves and Thomas (2008) as possibly affecting the internationalization of FBs. The division of firms into (for instance) FBs, non-FBs, and semi-FBs (Tsang, 2002), together with a search for similarities and differences in their internationalization behavior, could offer insights on the effects of differing degrees of family ownership. Such studies would follow up the research of Tsang (2002), who discovered that FBs had the most unstructured internationalization process, whereas non-FBs were obviously more strategic. Tsang's research further indicated that semi-FBs (with some FB-specific features ${ }^{7}$ ) had a certain degree of structure in their process, and were situated in between the other two groups.

\footnotetext{
${ }^{7}$ As stated earlier, no precise criteria for these different categories were found in the article by Tsang (2002).
} 
Furthermore, this perspective could put forward the findings of Sciascia et al. (in press) stating that internationalization is maximized when there is a moderate level of family ownership in the firm. In addition, a comparison of FBs with different numbers of or roles for family members in the management could improve our understanding of the issue.

(iv) Methodology. Concerning methodology, the studies we included tended to answer what questions rather than how questions and/or why questions. In the future, more case studies answering how and why questions will be are needed. They will make possible a deeper investigation of the phenomenon, and the identification of similarities and differences within several cases (Eisenhardt, 1989; Yin, 1994). Secondly, in research up to now, the focus has been on the manufacturing sector. In the future, service firms and both high and low technology FBs ought to be studied, bearing in mind the verified differences between the different categories (Bell et al., 2004; O'Farrell et al., 1997). The reporting of methodological issues in the articles was often limited. Hence, in further studies there should be more attention to adequately reporting the methodology, for the sake of the validity of the studies. In addition, to avoid biases due to individual opinions (Huber \& Power, 1985), the range of informants could be extended from executives to other persons involved in internationalization.

In the existing studies, the definition of a family business was most often based on ownership and management perspectives - although many variations were found. In the future, it would be good if the definition could be made more consistent. Another interesting alternative would be to look at whether internationalization is different when the definition of a family firm is based on all four criteria (ownership, management, continuity, subjective perception) or on one, or two, or three of them. Differences in types of family businesses - or business families - might well be related to differences in the internationalization process and its outcome. Clearly, investigations are needed to clarify this issue.

\section{Conclusions}

Altogether, several important contributions emerge from this study. To the best of our knowledge, this is the first academic article to introduce contemporary research on FB internationalization. Secondly, our study serves as a step towards identifying the kinds of background theories and methodologies that have been used to study FB internationalization, and determining what is currently known about the phenomenon. Most importantly, the study identifies various fruitful areas of research. The point we would emphasize is that current research on FB internationalization offers very limited knowledge on the processes and strategies that make FBs unique in their internationalization. We have therefore suggested the use of FB-specific perspectives that would provide the subfield of FB internationalization with a more holistic understanding of the features that distinguish FBs from other firms.

From a managerial perspective, FB managers ought to be aware of their strengths concerning the internationalization and take advantage of them. FB-specific advantages 
in the context of internationalization include a long-term view, a high level of trust, and the possibility to take quick decisions. The long-term commitment of FBs can help to assure potential partners and investors of the continuity of the process, and the high level of trust inside the firm can enhance the formation of outside network ties. In internationalization, the ability of FBs to make quick decisions can be especially important, since internationalization is a very dynamic process in which the ability to react quickly to new international opportunities can be critical. Furthermore, FB managers ought to minimize the effect of features that will tend to impede their internationalization, such as a domestic perspective, unstructured management processes, and limited networks. FB managers could overcome these disadvantages by increasing their knowledge of internationalization strategies and of different cultures. Other measures would include training the next generation, hiring outsiders within the management, regularly monitoring the international environment, and actively attending international occasions (such as trade exhibitions) where there is the chance to network with potential foreign partners.

\section{Acknowledgements}

The authors thank Mattias Nordqvist and the anonymous reviewers for their invaluable comments and suggestions on the earlier drafts of the manuscript.

\section{References}

Acedo, F.J., \& Casillas, J.C. (2005). Current paradigms in the international management field: An author co-citation analysis. International Business Review, 14, 616-639.

Adler, P.S., \& Kwon, S-W. (2002). Social Capital: Prospects for a New Concept. Academy of Management Review, 27(1), 17-40.

Arregle, J-L., Hitt, M.A., Sirmon, D.G., \& Very, P. (2007). The development of organizational social capital: Attributes of family firms. Journal of Management Studies, 44(1), 73-95.

Barney, J. (1991). Firm resources and sustained competitive advantage. Journal of Management, 17(1), 99-120.

Basly, S. (2007). The internationalization of family SME: An organizational learning and knowledge development perspective. Baltic Journal of Management, 2(2), 154-180.

Bell, J., Crick, D., \& Young, S. (2004). Small Firm Internationalization and Business Strategy. International Small Business Journal, 22(1), 23-56.

Bell, J., McNaughton, R., \& Young, S. (2001). ‘Born-again global' firms: An extension to the 'born global' phenomenon. Journal of International Management, 7, 173-189.

Bell, J., McNaughton, R., Young, S., \& Crick, D. (2003). Towards an integrative model of small firm internationalisation. Journal of International Entrepreneurship, 1(4), 339-362.

Carney, M. (2005). Corporate governance and competitive advantage in familycontrolled firms. Entrepreneurship Theory and Practice, 29(3), 249-265. 
Casillas, J.C., \& Acedo, F.J. (2005). Internationalisation of Spanish family SMEs: an analysis of family involvement. International Journal of Globalisation and Small Business, $1(2), 134-151$.

Casillas, J.C., \& Acedo, F.J. \& Moreno, A.M. (2007). International Entrepreneurship in Family Businesses, Edward Elgar Publishing, Cheltenham, UK.

Child, J., Ng, S.H., \& Wong, C. (2002). Psychic distance and internationalization: Evidence from Hong Kong firms. International Studies of Management \& Organization, 32(1), 36-56.

Chrisman, J.J., Steier, L.P., \& Chua, J.H. (2006). Personalism, Particularism, and the Competitive Behaviors and Advantages of Family Firms: An Introduction. Entrepreneurship Theory and Practice 30(6), 719-729.

Claver, E., Rienda, L., \& Quer, D. (2007). The internationalisation process in family firms: Choice of market entry strategies. Journal of General Management, 33(1), 1-14.

Claver, E., Rienda, L., \& Quer, D. (2008). Family firms' risk perception: Empirical evidence on the internationalization process. Journal of Small Business and Enterprise Development, 15(3), 457-471.

Coviello, N.E., \& McAuley, A. (1999). Internationalisation and the Smaller Firm: A Review of Contemporary Empirical Research. Management International Review, 39(3), 223-256.

Coviello, N.E., \& Jones, M.V. (2004). Methodological issues in international entrepreneurship research. Journal of Business Venturing, 19(4), 485-508.

Crick, D., Bradshaw, R., \& Chaudry, S. (2006). "Successful” internationalising UK family and non-family-owned firms: a comparative study. Journal of Small Business and Enterprise Development, 13(4), 498-512.

Davidson, W.H. (1983). Market Similarity and Market Selection: Implications for International Marketing Strategy. Journal of Business Research, 11, 439-456.

Davis, P.S., \& Harveston, P.D. (2000). Internationalization and organizational growth: The impact of internet usage and technology involvement among entrepreneur led family businesses. Family Business Review, 13(2), 107-120.

Dimitratos, P., \& Jones, M.V. (2005). Future directions for international entrepreneurship research. International Business Review, 14(2), 119-128.

Dunning, J. H. (1980). Toward an eclectic theory of international production: Some empirical tests. Journal of International Business Studies,11(1), 9-31.

Eisenhardt, K.M. (1989). Building theories from case study research. Academy of Management Review, 14 (4), 532-550.

Ellis, P. (2008). Social ties and international opportunity recognition. Unpublished manuscript, Hong Kong Polytechnic University.

Erdener, C., \& Shapiro D.M. (2005). The Internationalization of Chinese Family Enterprises and Dunning's Eclectic MNE Paradigm. Management and Organization Review, 1(3), 411-436.

Fernandez, Z., \& Nieto, M.J. (2005). Internationalization strategy of small and mediumsized family businesses: Some influential factors. Family Business Review, 18(1), 77-89. 
Fernandez, Z., \& Nieto, M.J. (2006). Impact of ownership on the international involvement of SMEs. Journal of International Business Studies, 37(3), 340-351.

Gallo, M.A., \& Pont, C.G. (1996). Important factors in family business internationalization. Family Business Review, 9(1), 45-59.

Gallo, M.A., \& Sveen, J. (1991). Internationalizing the family business: Facilitating and restraining factors. Family Business Review, 4(2), 181-190.

George, G., Wiklund, J., \& Zahra, S.A. (2005). Ownership and the Internationalization of Small Firms. Journal of Management, 31(2), 210-233.

Gomez-Mejia, L.R., Makri, M., \& Kintana, M.L. (2010). Diversification Decisions in Family-Controlled Firms. Journal of Management Studies, 47(2), 223-252.

Graves, C., \& Thomas, J. (2004). Internationalisation of the family business: a longitudinal perspective. International Journal of Globalisation and Small Business, 1(1), 7-27.

Graves, C., \& Thomas, J. (2006). Internationalization of Australian family businesses: A managerial capabilities perspective. Family Business Review, 19(3), 207-224.

Graves, C., \& Thomas, J. (2008). Determinants of the internationalization pathways of family firms: An examination of family influence. Family Business Review, 21(2), 151167.

Huber, G.P., \& Power, D.J. (1985). Retrospective Reports of Strategic-level Managers: Guidelines for Increasing their Accuracy. Strategic Management Journal, 6, 171-180.

Johanson, J., \& Matsson, L.-G. (1988). Internationalisation in Industrial Systems - A Nework Approach. In N. Hood \& J.-E. Vahlne (Eds.), Strategies in Global Competition (pp. 287-314). London: Croom Helm.

Johanson, J., \& Vahlne, J.-E. (1977). The internationalization process of the firm: A model of knowledge development and increasing foreign market commitments. Journal of International Business Studies, 8(1), 23-32.

Johanson, J., \& Vahlne, J. (2003). Business relationship learning and commitment in the internationalization process. Journal of International Entrepreneurship, 1(1), 83-101.

Johanson, J., \& Vahlne, J-E. (2009). The Uppsala internationalization process model revisited: From liability of foreignness to liability of outsidership. Journal of International Business Studies, 40, 1411-1431.

Johanson, J., \& Wiedersheim-Paul, F. (1975). The internationalization of the firm: Four Swedish cases. Journal of Management Studies, 12(3), 305-322.

Keupp, M.M., \& Gassmann, O. (2009). The Past and the Future of International Entrepreneurship: A Review and Suggestions for Developing the Field. Journal of Management, 35(3), 600-633.

Knight, G., \& Kim, D. (2009). International business competence and the contemporary firm. Journal of International Business Studies, 40, 255-273.

Kumar, V., \& Subramaniam, V. (1997). A Contingency Framework for the Mode of Entry Decision. Journal of World Business, 32(1), 53-72.

McKibbin, P., \& Pistrui, D. (1997). East meets west: Innovative forms of foreign trade finance between Italian family enterprises and emerging SMEs in Romania. Family Business Review, 10(3), 263-280. 
Menéndez-Requero, S. (2005). Growth and internationalization of family businesses. International Journal of Globalisation and Small Business, 1(2), 122-133.

Miller, D., Le Breton-Miller, I., \& Scholnick, B. (2008). Stewardship vs. Stagnation: An Empirical Comparison of Small Family and Non-Family Businesses. Journal of Management Studies, 45(1), 51-78.

O'Farrell, P.N., Wood, P.A., \& Zheng, J. (1997). Internationalisation by Business Service SMEs: An Inter-Industry Analysis. International Small Business Journal, 16(2), 13-33.

Ojala, A. (2008). Entry in a Psychically Distant Market: Finnish Small and Medium-sized Software Firms in Japan. European Management Journal, 26(2), 135-144.

Ojala, A. (2009). Internationalization of knowledge-intensive SMEs: The role of network relationships in the entry to a psychically distant market. International Business Review 18(1), 50-59.

Ojala, A., \& Tyrväinen, P. (2007). Market Entry and Priority of Small and Medium-Sized Enterprises in the Software Industry: An Empirical Analysis of Cultural Distance, Geographical Distance, and Market Size. Journal of International Marketing, 15(3), 123149.

Okoroafo, S.C. (1999). Internationalization of family businesses: Evidence from northwest Ohio, U.S.A. Family Business Review, 12(2), 147-158.

Oviatt, B.M., \& McDougall, P.P. (1994). Toward a theory of international new ventures. Journal of International Business Studies, 25(1), 45-64.

Pinho, J.-C. (2007). The impact of ownership: Location-specific advantages and managerial characteristics on SME foreign entry mode choices. International Marketing Review, 24(6), 715-734.

Salvato, C., \& Melin, L. (2008). Creating Value Across Generations in Family-Controlled Businesses: The Role of Family Social Capital. Family Business Review, 21(3), 259-276.

Sciascia, S., Mazzola, P., Astrachan, J.H., \& Pieper, T. (in press). The role of family ownership in international entrepreneurship: exploring nonlinear effects. Small Business Economics.

Sharma, P. (2004). An overview of the field of family business studies: Current status and directions for the future. Family Business Review, 17(1), 1-36.

Sirmon, D.G., Arregle, J.-L., Hitt, M.A., \& Webb, J.W. (2008). The Role of Family Influence in Firms' Strategic Responses to Threat of Imitation. Entrepreneurship Theory and Practice, 32(6), 979-998.

Sirmon, D.G., \& Hitt, M.A. (2003). Managing resources: Linking unique resources, management, and wealth creation in family firms. Entrepreneurship theory and practice 27(4), 339-358.

Svinth, R.L., \& Vinton, K.L. (1993). Do family-owned businesses have a strategic advantage in international joint ventures? Family Business Review, 6(1), 19-30.

Thomas, J., \& Graves, C. (2005). Internationalising the family firm as a demonstration of an entrepreneurial culture. Journal of Small Business and Entrepreneurship, 17(2), 91-113.

Transfield, D., Denyer, D., \& Smart, P. (2003). Towards a Methodology for Developing Evidence-Informed Management Knowledge by Means of Systematic Review. British Journal of Management, 14, 207-222. 
Tsang, E.W.K. (2001). Internationalizing the family firm: A case study of a Chinese family business. Journal of Small Business Management, 39(1), 88-94.

Tsang, E.W.K. (2002). Learning from overseas venturing experience: the case of Chinese family businesses. Journal of Business Venturing, 17(1), 21.

Vago, M. (1995). Why fish must learn to see the water they swim in. Family Business Review, 8(4), 313-325.

Wright, M., Westhead, P., \& Ucbasaran, D. (2007). Internationalization of Small and Medium-sized Enterprises (SMEs) and International Entrepreneurship: A Critique and Policy Implications. Regional Studies, 41(7), 1013-1029.

Yeung, H.W. (2000). Limits to the growth of family-owned business? The case of Chinese transnational corporations from Hong Kong. Family Business Review, 13(1), 55-70.

Yin, R.K. (1994). Case study research: Design and methods (2nd ed.), Newbury Park, CA: SAGE Publications.

Zahra, S.A. (2003). International expansion of U.S. manufacturing family businesses: The effect of ownership and involvement. Journal of Business Venturing, 18(4), 495-512.

Zahra, S.A., \& Sharma, P. (2004). Family business research: A strategic reflection. Family Business Review, 17(4), 331-346.

Zahra, S.A., Korri, J.S., \& Yu, J.F. (2005). Cognition and international entrepreneurship: implications for research on international opportunity recognition and exploitation. International Business Review, 14(2), 129-146. 